\title{
REGULATING FREE MOVEMENT OF GOODS WITHIN THE EUROPEAN UNION
}

\author{
Associate Professor Daniel Berlingher PhD \\ „Vasile Goldiş” Western University of Arad \\ E-mail: berlingherdaniel@yahoo.com
}

(Received: March 2018; Accepted: May 2018)

\begin{abstract}
The principle of the free movement of goods in one of great importance for the European Union and for in general and for the Internal Market and the European citizens in particular.

Starting from the fact that the Internal market is considered to be a critical element for the present and future prosperity of the European Union in a globalized world, the objective of the present text is to present and analyse, in a concise manner, the main legal provisions that govern this field.

In order to accomplish this objective we made reference to the following aspects: considerations regarding the role and importance of the free movement of goods in the European internal market; the role of the European Commission within the internal market and implicitly for the free movement of goods; Treaty provisions governing the free movement of goods; and related instruments of secondary law related to the free movement of goods.
\end{abstract}

Key words: free movement of goods, internal market, European integration, customs union, customs cooperation, quantitative restrictions

\section{Considerations regarding the role and importance of the free movement of goods in the European internal market}

In 1987 the Treaty of Rome (1950) suffered the first major revision through the Single European Act. The most important purpose of this act was to improve the European integration and also the common market that already existed. The act brought a considerable amendments to the rules governing the functioning of the European institutions and it expanded their powers in different fields. It was the moment when the leaders of the European Union decided that there was important to create new rules for completing the single market. This single market became a reality on the 1st of January 1993 for the 12 Member States. At the present moment, the internal market of the European Union encompasses 28 Member States, but despite this, it is far from achieving its full potential [1].

According to a Communication of the European Commission, an internal market for goods that is properly functioning represents a critical element for the present and future prosperity of the European Union in a globalised world [2]. 
Berlingher D. (2018)

Regulating free movement of goods within the European Union

Being adopted in two stages, the Single Market Acts I and II were meant to accomplish the full growth and employment potential by removing the obstacles that were preventing them [3].

The free movement of goods is one of the four cornerstones of the internal market - free movement of people, goods, services and capital. These freedoms are all regulated by the Treaty on the Functioning of the European Union, within the third part of the Treaty, Title I regarding "the internal market".

From a legal point of view, the principle of the free movement of goods is a key element for the creation and development of the internal market. The principle is also at the heart of the EU policies. The role and importance of this principle can be traced in the benefits that the European citizens and companies have as a consequence of the creation of the internal market - for example: buying and selling products has become easier, consumers have a wide choice of products and so they can find the best offer, free movement of goods is good for business, EU companies can build a strong platform in an opened, diverse and competitive environment, and they can also manage to obtain the resources they need in order to be successful in other world markets, the creation of new jobs within the European Union, etc.[4]

\section{The role of the European Commission within the internal market and implicitly for the free movement of goods}

As other authors have shown and as article 1 (2) of the TFEU provides, the treaties on which the Union is founded are, since the adoption of the Lisbon Treaty: the Treaty on the functioning of the European Union and the Treaty on the European Union, both of them having the same legal value. We must also recall the fact that after the adoption of this reforming treaty, TFEU is the one which organises the functioning of the Union, establishing the fields, the limits and the conditions in which the Union can exercise its competences [5].

Article 3 of the EU Treaty establishes that the Union has a unique institutional framework which is meant to ensure the coherence and continuity of the actions undertaken in order to attain its objectives [6]. According to the provisions of the EU Treaty the EU institutions have the power to adopt regulations, directives or decisions in different fields of action. We must specify from the beginning that in the area of the internal market, the Union and the Member States share competences [7].

The internal market comprises - according to the provisions of the TFEU - "an area without internal frontiers in which the free movement of goods, persons, services and capital is ensured in accordance with the provisions of the Treaties"[8]. For the good functioning of the internal market, the Union can adopt different measures in full accordance with the European law [9]. 
The provisions of the TFEU regarding the shared competences of the Union and the Member States in the field of the internal market - mentioned above - must be correlated with the ones regarding the customs union and which establish that in this area the Union has exclusive competence [10]. The Union has also exclusive competence in the area of establishing the competition rules for the functioning of the internal market [11].

Among the EU institutions, the European Commission has a very important role in proposing EU legislation, upholding the EU treaties, and also in ensuring that the EU law is properly applied in all the Member States of the European Union [12]. Through its proposals, the Commission helps the Council determine the guidelines and the conditions that are considered to be necessary for a balanced progress of the internal market [13].

At the same time, we must notice the multitude of tools that the European Commission has at its disposal to ensure the good functioning of the internal market. The main ways through which the European Commission acted in the past consisted in the adoption of new legal provisions and the legal actions taken against the Member States. Nowadays, the European Commission has a more practical and ambitious approach - through enhancing the cooperation between the Commission and the Member States and their citizens and companies in the field of the internal market; through IT tools and Internet; also - in response to the financial and economic crisis - through adopting key measures that were destined to create a deeper and better integrated internal market [14].

In using all these tools, the European Commission must take into consideration the existing differences between the economies of the Member States and also the amount of effort that they must undertake in order to sustain the development of the internal market. In doing so, the Commission must adapt its legal proposals which can sometimes take the form of temporary derogations in order not to cause a great disturbance to the functioning of the internal market [15].

\section{Treaty provisions governing the free movement of goods}

The main Treaty provisions that are governing the free movement of goods can be found in the third part of TFEU, Title II - Free movement of goods. The Title is divided into three chapters: The customs Union, Customs cooperation, and Prohibition of quantitative restrictions between Member States.

In order to understand the principle of the free movement of goods we must first of all make reference to the customs union, to the customs cooperation and also to the aspect of prohibiting quantitative restrictions between Member States.

According to the provisions of TFEU the customs union must cover all trade in goods. Also, the customs union prohibits all customs duties on imports and exports and all charges having an equivalent effect between the Member States. More than 
Berlingher D. (2018)

Regulating free movement of goods within the European Union

that, the customs union means the adoption of a common customs tariff in the relations with third countries [16].

The chapter governing the customs union establishes two important aspects. The first legal provision refers to the customs duties on imports and exports, to the customs duties of fiscal nature, and to the charges that have equivalent effect, establishing that all these are prohibited between Member States. These provisions apply both to the products that have their origin within the Member States and to the ones that are coming from third countries and which are in free circulation in the Member States [17].

The research literature shows that eliminating customs duties and other restrictive commercial regulation is specific to any area of free trade. This model was adopted also by the European Free Trade Association (E.F.T.A.) created on the $4^{\text {th }}$ of January 1960. The model promoted by G.A.T.T. (1947) - of creating an area of free trade - was adopted in the European Union [18].

In order to understand the notion of "customs union" Sergiu Deleanu believes that we must take into consideration a few aspects regarding the fields of application of the provisions related to this notion. The author mentions three fields of application: territorial, material and temporal [19]. The classification was exposed by the research literature with reference to the differentiated integration - when Alexandre Stubb talked about "ratione materiae diversity, ratione temporis diversity and ratione loci diversity" [20] - and it was referred to on many occasions as for example when talking about the conceptualization of enhanced cooperation or the principle of flexibility [21].

With reference to the territorial field of application we must mention the fact that the customs territory is defined in Article 3 of the Regulation No. 450/2008 regarding the establishment of the Community Customs Code [22]. According to these provisions, the customs territory of the European Union comprises the territories of the Member States, including their territorial waters, internal waters and airspace [23].

The material field of application of the customs union is regarding all the economic sectors because according to Article 28 (1) of the TFEU, the customs union regulates the trade of goods.

The ECJ stated in its jurisprudence that through the term "good" we must understand any good that passes through a frontier in order to be traded [24].

The principle of the free movement of goods applies to the goods that have their origin within the Member States (Article 28 par. 2 of the TFEU). TFEU does not define the term "goods". So, in order to do so we must make reference to the legal provisions established in Article 4 (18) of the Community Customs Code and which establish that "Community goods" are the goods that can be found in one of the following categories of goods: 
- " (a) goods wholly obtained in the customs territory of the Community and not incorporating goods imported from countries or territories outside the customs territory of the Community",

- " "(b) goods brought into the customs territory of the Community from countries or territories outside that territory and released for free circulation", or

- " (c) goods obtained or produced in the customs territory of the Community, either solely from goods referred to in point (b) or from goods referred to in points (a) and (b)".

Here we must also make reference to Article 29 of the TFEU which states that there are considered to be in free circulation in the Member State the products coming from third countries if the import formalities have been complied with and the custom duties or charges with an equivalent effect have been levied in that Member State and if they did not benefit from a total or partial drawback of such duties or charges [25].

Putting goods into free circulation can involve the application of some measures of trade policy that can be prohibitive or restrictive. The goods can be put in free circulation only after being submitted to the administrative procedure of the customs. Putting the goods info free circulation confers the goods coming from third countries the customs status of Community goods [26].

The last field of application, the temporal one, refers to the period of time in which the customs union was created - the 1st of July 1968. It was a lent rhythm and through a flexible procedure in order not to affect the economy of the Member States [27].

The second aspect refers to the role of the European Commission within the customs union. According to the legal provisions, in exercising its role, the European Commission makes proposals to the Council regarding the common customs tariff duties. To this respect, the European Commission must be guided by the following aspects [28]:

- The necessity to promote trade between Member States and third countries,

- The evolution of the conditions of competition within the Union if this evolution is meant to improve the competitive capacity of the companies,

- The need for raw materials and semi-finished goods within the Union - the Commission must pay attention not to disturb the conditions of competition between Member States in respect of the finished goods,

- The necessity to avoid serious disturbances in the economies of the Member States,

- The need to ensure a rational development and the expansion of consumption within the Union.

The customs cooperation is regulated by Article 33 TFEU, which refers to the cooperation between the European institutions in the field of free movement of 
goods. So, according to these legal provisions, the European Parliament and the Council are the ones which adopt measures in order to enhance the customs cooperation between the Member States and also between the Member States and the European Commission. According to the same legal provisions, these measures are adopted by the Parliament and the Council according to the ordinary legal procedure [29].

The third chapter of the second Title of TFEU contains provisions regarding the prohibition of quantitative restrictions between Member States.

Article 34 of the TFEU refers to the imports between the Member States and it clearly prohibits quantitative restrictions and all measures having equivalent effect.

The provisions of Article 34 apply without making any distinction between the goods produced in the Member States and the ones that are in free circulation in any other Member State [30].

In the same manner, Article 35 of the TFEU relates to the exports between the Member States and it also prohibits quantitative restrictions and all measures having equivalent effect.

The prohibitions established by Articles 34 and 35 do not have an absolute character. Quantitative restrictions and the measures with an equivalent effect can be justified in some cases.

Article 36 of the TFEU establishes the legal limits to the provisions of Articles 34 and 35 of the TFEU, stating that there are some derogations to the internal market freedoms (imports, exports and transit between the Member States). These derogations are justified on the following specific grounds:

- Public morality, public policy or public security,

- The protection of health and life of humans, animals or plants,

- The protection of national treasures possessing artistic, historic or archaeological value,

- The protection of industrial and commercial property.

Article 36 of the TFEU also provides that such grounds must not represent a means of arbitrary discrimination or even disguised restrictions on trade between Member States.

The exceptions stated in Article 36 refer only to the quantitative restrictions to import or export and to the measures with an equivalent effect. These provisions cannot be invoked in order to introduce exceptions in the field of customs taxes, of the taxes with an equivalent effect or of the internal duties. The exceptions mentioned above can justify either the existence or the creation of some quantitative restrictions or of some measures with an equivalent effect to import or to export. We must also mention that the exceptions provided in Article 36 are of strict and limited interpretation [31]. 
Article 37 of the TFEU establishes a few rules regarding the adjustment of state monopolies of a commercial character. According to the first paragraph of this Article, the Member States must adjust their state monopolies of a commercial character so that they ensure the exclusion of any discrimination between the nationals of the Member States regarding the conditions under which goods are procured and marketed.

According to the second part of the first paragraph of this article, its provisions apply to any organism through which a Member State, in law or in fact, directly or indirectly, controls, leads or influences in a significant manner, the imports and the exports between the Member States. Its provisions also apply to the monopolies delegated by the State to others.

In order to respect the principles mentioned in the second Title of the TFEU, the Member States must refrain from introducing any new contrary measure [32].

Also, in case of a commercial monopole in the agricultural field - that could mean providing a regulation concerning the disposal of the agricultural products - the Member States must ensure the equivalent guarantees for the employment and standard of living of the producers concerned [33].

These provisions are relevant specially in the context of analysing the rules applicable in the field of competition, because the presence of state monopolies with a commercial character has a great impact on the behaviour of the enterprises which are present on the internal market [34].

4. Related instruments of secondary law related to the free movement of goods Directive 98/34/EC - providing a procedure for the provision of information in the field of technical standards and regulations and of rules on information society services - obliges the Member States to notify the Commission and their counterparts of any draft technical regulation relating to products and, starting with 1999 , to information society services before they are adopted in their national laws [35].

According to the provisions of this Directive, the European Commission and the Member States were meant to operate through a system of preventive control. During the standstill periods, Member States were not supposed to adopt their notified draft regulations for at least three months while they were being examined. This period could be extended up to 18 months in case the measure in question determined the creation of some unjustified obstacles to trade or in case the harmonisation process was in progress at EU level in the area covered by the notified draft.

This procedure was meant to eliminate any barriers to the well functioning of the internal market. These barriers were being eliminated even before they appeared. So, we talk about prevention rules, as the national drafts were adapted to the EU 
Berlingher D. (2018)

Regulating free movement of goods within the European Union

law before being adopted. More than that, the national drafts could be submitted to a waiting process for a certain period of time necessary in order to facilitate the debate at EU level [36].

The directive is no longer into force as it was replaced by Directive (EU) 2015/1535 of the European Parliament and of the Council [37] which codifies and at the same time abolishes Directive 98/34/EC. Directive (EU) 2015/1535 entered into force on the $7^{\text {th }}$ of October 2015 and since then the Member States have the obligation to make reference to it when they make any technical regulation.

The new Directive continues to place an obligation on Member States to notify the European Commission any draft technical regulations that fall into the scope of the Directive and also to operate a "standstill period" of at least three months before adopting the draft regulations. This procedure gives the Commission and the Member States the possibility to consider and to provide comments on the draft proposals [38].

So, according to the provisions of this Directive, the Member States must inform the Commission about any new technical regulations and standards at the moment they are drafted and not yet adopted in national law. Once notified, the measure will enter into a "standstill period" that will usually last for three months. During this period of time the measure cannot be adopted on a national level. This period of time gives the Commission and the Member States the possibility to analyse the draft and see whether it represents a potential barrier to trade [39].

The Directive applies to "information society services" and to all industrially manufactured products and agricultural products. The scope of the Directive can include: laws, regulations or administrative provisions of a Member State; voluntary agreements to which a public authority is a contracting party; technical specifications or other requirements or rules on services which are connected to fiscal or financial measures that affect consumption of products or services [40].

Regulation (EC) No. 2679/98 - "the strawberry regulation" - on the functioning of the internal market in relation to the free movement of goods among the Member States - provides a special procedure for combating the serious obstacles to the free movement of goods between the Member States that can determine serious losses for the individuals affected and which require immediate action. Such serious obstacles can be the result of the passivity of the national authorities in the face of violent action by individuals, or non-violent blockages of the borders, or even of action by a Member State - as an institutionalized boycott of imported products [41].

This regulation establishes an alert procedure and also the exchange of information between the Member States and the European Commission. It also reminds Member States that they have the obligation to adopt all the necessary and proportionate measures in order to ensure the free movement of goods and to 
inform the European Commission about such demarches. In turn, the regulation empowers the European Commission to notify the Member States about the adoption of such measures within a certain period of time [42].

The Regulation defines the term "obstacle" to the free movement of goods as being the action or inaction of a Member State - which leads to "serious disruption of the free movement of goods by physically or otherwise preventing, delaying or diverting their import into, export from or transport across a Member State"; or which causes serious losses "to the ones affected; or which requires an immediate action in order to prevent any continuation, increase or intensification of the disruption or loss in question" [43].

According to the Report from the Commission to the Council and the European Parliament on the application of Regulation (EC) No. 2679/98, the Regulation has a few weaknesses. The first category of weaknesses refers to the lack of any penalty in case a Member State holds information on an obstacle and it does not fulfil the information obligation provided by Article 3 (1, a) of the Regulation. Also, the Regulation does not provide for any penalty in case the Member State refuses to reply to a request from the Commission for information (as provided in Article 3(2) of the Regulation) or of a notification (as provided in Article 5 of the Regulation. The Regulation does not provide a penalty in case the Member State omits to inform the Commission when it takes the measures necessary for ensuring the free movement of goods [44].

The second category of weaknesses presented by the Commission refers to the fact that the scope of Article 5 of the Regulation is, at the present moment, too limited because it can be applied only when the obstacle produces [45].

The third category of weaknesses refers to the definition of the scope of the Regulation - as it is presented in Article 1 - considered to be too abstract and opened to different interpretations. Defining the scope of the Regulation means, according to the Commission, presenting the type and nature of the necessary and proportionate measures which must be taken by the Member States in order to ensure the free movement of goods in the event of an obstacle[46].

Finally, the last category of weaknesses of the Regulation presented above refers to the fact that it does not resolve in an effective manner the question of speedy and effective complaint procedures for compensating the economic operators [47].

According to the European Commission, the existing legal framework calls for improving cooperation with the Member States in the following directions: prompt information on the threats of obstacles, detailed and prompt responses to the Commission's requests for information, and the adoption of supporting measures to restore the free movement of goods on the territory of the Member States. The Commission considers that the Member States are directly responsible for the improvement of this cooperation [48]. 
Furthermore, the Commission thinks that the application of the Regulation must be done more dynamically through the existing tools and without amending the existing legal framework. Such an amendment of the Regulation would be useful mainly for extending and improving its scope [49].

Regulation (EC) No. 764/2008 - "the mutual recognition regulation" - establishing a procedure regarding the application of certain technical rules to the products marketed in another Member State, defines the rights and obligations of the national authorities and businesses in case the national authorities try to deny mutual recognition and refuse market access of a product marketed in another Member State [50].

According to the provisions of the regulation mentioned above the national authorities that intend to deny mutual recognition or refuse the access of a product marketed in another Member State must prove the reasons invoked by setting out in writing the technical or scientific reason for their intention. The economic operator has the chance to defend its case and to bring solid arguments in order to combat the intention of the national authorities.

The regulation also provides the creation of "product contact points" in each Member State. These product contact points must provide information about the technical rules on products and also about the implementation of the mutual recognition principle to the enterprises and to the national authorities in other Member States.

The aim of this Regulation is to strengthen the functioning of the internal market by improving the free movement of goods [51].

The Regulation applies to administrative decisions addressed to economic operators, with reference to any product, including agricultural and fish products that are marketed in another Member State, where the direct or indirect effect of that decision consists in: "the prohibition of the placing on the market of that product or type of product; the modification or additional testing of that product or type of product before it can be placed or kept on the market; the withdrawal of that product or type of product from the market" [52].

Chapter II of the Regulation contains provisions regarding the procedure for the application of a technical rule and chapter III refers strictly to the creation of the product contact points. In the chapter referring to the final previsions it is established that Member States have the obligation to send the Commission a report every year regarding the application of this Regulation. The report must include at least the number of written notices sent by the competent authorities and the type of products concerned, information concerning the decisions taken, and also the number of such decisions.

In the first Report on the application of the Regulation, the European Commission insists on the fact that the major problem for implementing the principle of mutual 
recognition was the lack of legal certainty about the burden of proof. This was mainly the reason why this Regulation was adopted. The Regulation placed the burden of proof on the national authorities that intend to deny market access. To this effect, the Commission considers that the philosophy of this Regulation follows the approach of combining transparency - regarding information that must be exchanged between enterprises and national authorities - and efficiency - by avoiding any duplication of checks and testing [53].

The Commission believes that the main value of this Regulation consists in the way it succeeded to reduce information costs and so, it succeeded to facilitate the exploitation of free movement of goods and of mutual recognition [54].

Even though the Commission has taken different measures consisting in the elaboration of guidance documents on the application of the Regulation mentioned above, if concluded that mutual recognition in general and the application of the Regulation in particular, it cannot always offer a solution that could ensure the free movement of goods on the internal market. To this effect, the Commission states that one of the most effective instruments both for economic operators and for the national administrations remains harmonization [55].

\section{Conclusions}

The issue of the free movement of goods in one of great importance for the European Union and for in general and for the Internal Market and the European citizens in particular.

The main objective of our text was to present and analyse, in a concise manner, the main legal provisions that govern this field.

In doing so, we structured our text into four main parts dedicated to the following aspects: considerations regarding the role and importance of the free movement of goods in the European internal market; the role of the European Commission within the internal market and implicitly for the free movement of goods; Treaty provisions governing the free movement of goods; and related instruments of secondary law related to the free movement of goods.

The internal market of the European Union was characterized by the European Commission as being a critical element for the present and future prosperity of the European Union in a globalized world. At the basis of a well functioning internal market we can find the four fundamental freedoms of movement regarding: goods, people, services and capital - all regulated by the provisions of TFEU.

The principle of the free movement of goods represents the key element for the creation and development of the internal market. Being at the heart of the EU policies, the principle of the free movement of goods has developed many benefits for the European citizens and companies - some of them presented, in an exemplified manner, in the first part of our text. 
In an area with shared competences - the area of the internal market - the Treaty integrated a field in which the Union has exclusive competence - the customs union.

Among the EU institutions which are involved in the decision-making process, the European Commission has a very important role within the internal market. Through different proposals the Commission helps the Council to create the guidelines and the conditions necessary for the well functioning and progress of the internal market.

The European Commission has developed over time a more practical approach regarding the way it helps to the creation of a deeper and better integrated internal market: enhanced cooperation, IT tools, Internet, the adoption of key measures for improving the internal market.

In accomplishing its duties, the European Commission always took into consideration the existing differences between the economies of the Member States and the effort that they had to make in order to adapt to the European Union's demands.

In the third part of our text we made reference to the provisions of the TFEU relating to three main fields that characterize the issue submitted to our analyse: the customs union, the customs cooperation and the aspect of prohibiting quantitative restrictions between the Member States - Articles 28-37 of the TFEU.

We shortly presented and analysed these legal provisions making reference to the research literature in the field, to the jurisprudence or ECJ, to the provisions of TEU and to Regulation (EC) No. 450/2008 laying down the Community Customs Code.

In the last part of the text we mainly presented some relevant instruments of secondary law related to the free movement of goods: Directive 98/34/EC - no longer into force and replaced by Directive (EU) 2015/1535 - laying down a procedure for the provision of information in the field of technical regulations and of rules on information Society services; Regulation (EC) No. 2679/98 on the functioning of the internal market in relation to the free movement of goods among the Member States; and Regulation (EC) No. 764/2008 establishing a procedure regarding the application of certain technical rules to the products marketed in another Member State.

When analysing these instruments of secondary law, we presented their scope and main objectives. The two Regulations were, in addition, analysed through the angle of the Reports of the European Commission regarding their application.

\section{Bibliography}

1. Ancheş, Diana-Ionela, Preocupări juridice privind Uniunea Europeană, Ed. Eikon, ClujNapoca, 2014. 
2. Ancheş, Diana-Ionela, "The European Citizen's Initiative", in vol. Valentin Naumescu (ed.), Democracy and Security in the 21st Century. Perspective on a Changing World, Cambridge Scholars Publishing, Newcastle upon Tyne, 2014.

3. Ancheş, Diana-Ionela, "The Lisbon Treaty and the EU's Institutional System", in vol. Journal of Legal Studies, Biannual Journal, New Series, vol. VII-XIV, Issues 13-27, June 2014, Ed. Eikon, Cluj-Napoca.

4. Ancheş, Diana-Ionela, "Tratatul de la Lisabona şi sistemul instituţional al Uniunii Europene", in vol. Flore Pop, Oana Albescu (eds.), Tratatul de la Lisabona. De la "metoda comunitară" la noile evoluții ale guvernanței europene. Drept și politici ale Uniunii, CA Publishing, Cluj-Napoca, 2012.

5. Commission of the European Communities, Report from the Commission to the Council and the European Parliament on the application of Regulation (EC) No. 2679/98, COM 2001/160, Brussels, 22.03.2001, http://ec.europa.eu/transparency/regdoc/rep/1/2001/EN/1 2001-160-EN-F1-1.Pdf.

6. Communication from the Commission to the European Parliament, the Council and the European Economic and Social Committee, The internal market for goods: a cornerstone of Europe's competitiveness, Brussels, 14.2.2007, COM (2007)35 final, http://eurlex.europa.eu/legal-content/EN/TXT/PDF/?uri=CELEX:52007DC0035\& from=EN.

7. Consolidated version of the Treaty on the Functioning of the European Union, Official Journal of the European Union, C326/51, 26.10.2012, http://eur-lex.europa.eu/resource. html?uri=cellar:2bf140bf-a3f8-4ab2-b506-fd71826e6da6.0023.02/DOC_2\&format=PDF.

8. Council Regulation (EC) No. 2679/98 of 7 December 1998, on the functioning of the internal market in relation to the free movement of goods among the Member States, L 337/8, Official Journal of the European Communities, http://eur-lex.europa.eu/legalcontent/EN/TXT/PDF/?uri=CELEX:31998R2679\&from=EN.

9. Deleanu, Sergiu, Drept european al afacerilor, Piaţa internă a Uniunii Europene, Universul Juridic, Bucureşti, 2013.

10. Department for Business, Innovation and Skills, Directive 2015/1535/EU, Guidance for Officials, January 2016, https://www.gov.uk/government/uploads/system/uploads/ attachment_data/file/490271/BIS-16-15-directive-2015-1535-guidance.pdf.

11. Directive 98/34/EC of the European Parliament and of the Council of 22 June 1998 laying down a procedure for the provision of information in the field of technical standards and regulations, L204/37, http://eur-lex.europa.eu/legal-content/EN /TXT/PDF/?uri= CELEX:31998L0034\&from=RO.

12. Directive (EU) 2015/1535 of the European Parliament and of the Council of 9 September 2015, laying down a procedure for the provision of information in the field of technical regulations and of rules on Information Society services (codification), http://eurlex.europa.eu/legal-content/EN/TXT/PDF/?uri=CELEX:32015L1535\&from =ro.

13. ECJ, Case C-2/90, the 2nd of July 1992, Commission contre Belgique, in Recueil, $1992-8$, p. I-4478.

14. European Commission, The European Union explained, From crisis to opportunity putting citizens and companies on the path to prosperity, Publications Office of the European Union, Luxembourg, 2014, http://eudirect.ipng.hr/ Data/Files/15071692024448.pdf. 
Berlingher D. (2018)

Regulating free movement of goods within the European Union

15. European Commission, Free movement of goods, Guide to the application of Treaty provisions governing the free movement of goods, Publications Office of the European Union, Luxembourg, 2010.

16. European Commission, Communication from the Commission to the European Parliament and Council, First Report on the application of Regulation (EC) No. 764/2008 of the European Parliament and of the Council of 9 July 2008 laying down procedures relating to the application of certain national technical rules to products lawfully marketed in another Member State and repealing Decision No. 3052/95/EC, COM (2012) 292, Brussels, 15.6.2012, content/EN/TXT/PDF/?uri=CELEX:52012DC0292\&from=EN.

17. O’Neill, Aidan, EU Law for UK Lawyers, Hart Publishing, Oxford, 2011.

18. Regulation (EC) No. 450/2008 of the European Parliament and of the Council of 23 April 2008, laying down the Community Customs Code (Modernised Customs Code), http://eur-lex.europa.eu/LexUriServ/LexUriServ.do?uri=OJ:L:2008:145:0001:0064

:En:PDF.

19. Regulation (EC) No. 764/2008 of the European Parliament and of the Council of 9 July 2008 , laying down procedures relating to the application of certain national technical rules to products lawfully marketed in another Member State and repealing Decision No. 3052/95/EC,http://eur-lex.europa.eu/LexUriServ/LexUriServ.do?uri= OJ:L:2008:218:0021: 0029:en:PDF.

20. Stubb, Alexandre, "The semantic indigestion of differentiated integration: the political rhetoric of the pre-IGC debate", Collège d'Europe, 1995, in Claude Blumann, Luis Dubois, Droit institutionnel de l'Union Européenne, Editions du Juris-Classeur, Paris, 2004.

\section{Notes}

1. European Commission, The European Union explained, From crisis to opportunity putting citizens and companies on the path to prosperity, Publications Office of the European Union, Luxembourg, 2014, pp. 3-4, http://eudirect.ipng.hr/_Data/Files/ 15071692024448.pdf.

2. Communication from the Commission to the European Parliament, the Council and the European Economic and Social Committee, The internal market for goods: a cornerstone of Europe's competitiveness, Brussels, 14.2.2007, COM (2007)35 final, p. 11, http://eur-lex.europa.eu/legal-content/EN/TXT/PDF/?uri=CELEX:52007 DC0035 $\&$ from $=\mathrm{EN}$.

3. European Commission, The European Union explained, From crisis to opportunity putting citizens and companies on the path to prosperity, op. cit., p. 5.

4. European Commission, Free movement of goods, Guide to the application of Treaty provisions governing the free movement of goods, Publications Office of the European Union, Luxembourg, 2010, p. 10.

5. See: Diana-Ionela Ancheş, "Tratatul de la Lisabona şi sistemul instituţional al Uniunii Europene", in vol. Flore Pop, Oana Albescu (eds.), Tratatul de la Lisabona. De la "metoda comunitară" la noile evoluții ale guvernanței europene. Drept și politici ale Uniunii, CA Publishing, Cluj-Napoca, 2012, pp. 200-201; Diana-Ionela Ancheș, "The Lisbon Treaty and the EU's Institutional System", in vol. Journal of Legal Studies, 
Regulating free movement of goods within the European Union

Biannual Journal, New Series, vol. VII-XIV, Issues 13-27, June 2014, Ed. Eikon, ClujNapoca, pp. 134-135.

6. Diana-Ionela Ancheş, "The European Citizen's Initiative", in vol. Valentin Naumescu (ed.), Democracy and Security in the 21st Century. Perspective on a Changing World, Cambridge Scholars Publishing, Newcastle upon Tyne, 2014, pp. 226-227.

7. See Article 4, par. 2 (a) - Consolidated version of the Treaty on the Functioning of the European Union, Official Journal of the European Union, C326/51, 26.10.2012, http://eur-lex.europa.eu/resource.html?uri= cellar:2bf140bf-a3f8-4ab2-b506-fd71826 e6da6.0023.02/DOC_2\&format=PDF.

8. Ibid., Article 26, par. 2.

9. Ibid., Article 26, par. 1.

10. Ibid., Article 3 par. 1 (a).

11. Ibid., Article 3 par. 1 (b).

12. European Commission, The European Union explained, From crisis to opportunity putting citizens and companies on the path to prosperity, op. cit., p. 3.

13. Article 26, par. 3 - Consolidated version of the Treaty on the Functioning of the European Union, op. cit. supra.

14. European Commission, The European Union explained, From crisis to opportunity putting citizens and companies on the path to prosperity, op. cit., p. 5.

15. Article 27 - Consolidated version of the Treaty on the Functioning of the European Union, op. cit. supra.

16. Ibid., Article 28 par. 1.

17. See Articles 30 and 28 par. 2 of the Consolidated version of the Treaty on the Functioning of the European Union, op. cit. supra.

18. Sergiu Deleanu, Drept european al afacerilor, Piaţa internă a Uniunii Europene, Universul Juridic, Bucureşti, 2013, p. 59.

19. Id.

20. Alexandre Stubb, "The semantic indigestion of differentiated integration: the political rhetoric of the pre-IGC debate", Collège d'Europe, 1995, in Claude Blumann, Luis Dubois, Droit institutionnel de l'Union Européenne, Editions du Juris-Classeur, Paris, 2004.

21. Diana-Ionela Ancheş, Preocupări juridice privind Uniunea Europeană, Ed. Eikon, ClujNapoca, 2014, pp. 165-167.

22. Regulation (EC) No. $450 / 2008$ of the European Parliament and of the Council of 23 April 2008, laying down the Community Customs Code (Modernised Customs Code), http://eur-lex.europa.eu/LexUriServ/LexUriServ. do?uri=OJ:L:2008:145:0001:0064:En:PDF.

23. See Article 52 of the T.E.U. and Article 355 of the T.F.E.U.

24. ECJ, Case C-2/90, the 2nd of July 1992, Commission contre Belgique, in Recueil, 1992-8, p. I-4478.

25. Consolidated version of the Treaty on the Functioning of the European Union, op. cit. supra.

26. Sergiu Deleanu, op. cit., p. 62.

27. Ibid., p. 64. 
Berlingher D. (2018)

Regulating free movement of goods within the European Union

28. Articles 31 and 32 of the Consolidated version of the Treaty on the Functioning of the European Union, op. cit. supra.

29. Ibid., Article 33.

30. Sergiu Deleanu, op. cit., p. 82.

31. Ibid., p. 113.

32. Article 37, par. 2, Consolidated version of the Treaty on the Functioning of the European Union, op. cit. supra.

33. Ibid., Article 37, par. 3.

34. Sergiu Deleanu, op. cit., p. 127.

35. Directive 98/34/EC of the European Parliament and of the Council of 22 June 1998 laying down a procedure for the provision of information in the field of technical standards and regulations, L204/37, http://eur-lex.europa.eu/legal-content/ EN/TXT/ $\mathrm{PDF} /$ ?uri=CELEX:31998L0034\&from=RO.

36. European Commission, Free movement of goods, op. cit., 2010, p. 36.

37. Directive (EU) 2015/1535 of the European Parliament and of the Council of 9 September 2015, laying down a procedure for the provision of information in the field of technical regulations and of rules on Information Society services (codification), http://eur-lex.europa.eu/legal-content/EN/TXT/PDF/?uri=CELEX:32015 L1535\&from $=$ ro.

38. Department for Business, Innovation and Skills, Directive 2015/1535/EU, Guidance for Officials, January 2016, https://www.gov.uk/government/uploads/system/uploads /attachment_data/file/490271/BIS-16-15-directive-2015-1535-guidance.pdf.

39. Articles 5 and 6 - Directive (EU) 2015/1535, cit. supra.

40. Article 1 (f) - Directive (EU) 2015/1535, cit. supra.

41. Council Regulation (EC) No. 2679/98 of 7 December 1998, on the functioning of the internal market in relation to the free movement of goods among the Member States, $\mathrm{L}$ 337/8, Official Journal of the European Communities, http://eur-lex.europa.eu/legalcontent/EN/TXT/PDF/?uri=CELEX:31998R2679\&from=EN; Aidan O’Neill, EU Law for UK Lawyers, Hart Publishing, Oxford, 2011, pp. 802-805.

42. European Commission, Free movement of goods, op. cit., 2010, p. 36.

43. Article 1 - Council Regulation (EC) No. 2679/98, cit. supra.

44. Commission of the European Communities, Report from the Commission to the Council and the European Parliament on the application of Regulation (EC) No. 2679/98, COM 2001/160, Brussels, 22.03.2001, p. 10, http://ec.europa.eu/transparency

45. Id. /regdoc/rep/1/2001/EN/1-2001-160-EN-F1-1.Pdf.

46. Id.

47. Id.

48. Ibid., pp. 13-14.

49. Ibid., p. 14.

50. Regulation (EC) No. 764/2008 of the European Parliament and of the Council of 9 July 2008, laying down procedures relating to the application of certain national technical rules to products lawfully marketed in another Member State and repealing Decision 
Regulating free movement of goods within the European Union
No. 3052/95/EC,
http://eur-lex.europa.eu/LexUriServ/LexUriServ.do?uri= OJ:L:2008:218:0021:0029:en:PDF.

51. Article 1 (1) of Regulation (EC) No. 764/2008, cit. supra.

52. Article 2 (1) of Regulation (EC) No. 764/2008, cit. supra.

53. European Commission, Communication from the Commission to the European Parliament and Council, First Report on the application of Regulation (EC) No. 764/2008 of the European Parliament and of the Council of 9 July 2008 laying down procedures relating to the application of certain national technical rules to products lawfully marketed in another Member State and repealing Decision No. 3052/95/EC, COM (2012) 292, Brussels, 15.6.2012, pp. 5-6, http://eur-lex.europa.eu/legalcontent/EN/TXT/PDF/?uri=CELEX:52012DC0292\&from=EN.

54. Ibid., p. 6.

55. Ibid., pp. 11-13. 